\title{
Hubungan Ketepatan Terminologi Medis dengan Keakuratan Kode Diagnosis Rawat Jalan oleh Petugas Kesehatan di Puskesmas Bambanglipuro Bantul
}

\author{
Defa Miftara Agustine ${ }^{1}$, Rita Dian Pratiwi ${ }^{2}$ \\ Diploma III Rekam Medis Sekolah Vokasi UGM ${ }^{1}, 2$ \\ miftara.agustine@gmail.com ${ }^{1}$, ritadianp@ugm.ac.id ${ }^{2}$
}

\begin{abstract}
ABSTRAK
Latar Belakang: Semua pelayanan medis dan non medis di Puskesmas harus didokumentasikan dalam suatu berkas disebut rekam medis. Salah satu data yang dituliskan dalam berkas rekam medis, SIMPUS, dan P-Care adalah diagnosis dan kodenya. Pelaksanaan sistem klasifikasi klinis dan kodefikasi penyakit yang berkaitan dengan kesehatan harus sesuai terminologi medis yang benar. Pemberian kode diagnosis ini berdasarkan pada sistem klasifikasi penyakit yang ditetapkan oleh WHO saat ini yaitu ICD-10. Hasil studi dokumentasi terhadap 10 sampel berkas rekam medis rawat jalan yang dikode oleh petugas kesehatan, ditemukan $60 \%$ kode tidak akurat dan $80 \%$ terminologi medis tidak tepat atau tidak sesuai dengan ICD-10.

Tujuan: Mengetahui hubungan ketepatan terminologi medis dengan keakuratan kode diagnosis rawat jalan oleh petugas kesehatan di Puskesmas Bambanglipuro Bantul.

Metode: Jenis penelitian ini adalah survei analitik dengan pendekatan kuantitatif. Rancangan penelitian yang digunakan adalah cross-sectional. Populasi dalam penelitian ini adalah semua diagnosis rawat jalan beserta kodenya selama bulan Januari 2017. Teknik sampling yang digunakan yaitu systematic random sampling. Analisis data menggunakan analisis bivariate dengan program R.

Hasil: Dari sampel sebanyak 360 diagnosis rawat jalan beserta kodenya, terdapat $82(22,8 \%)$ terminologi medis tepat dan $278(77,2 \%)$ terminologi medis tidak tepat, serta kode diagnosis rawat jalan akurat sebanyak 127 (35,3\%) kode dan kode diagnosis rawat jalan tidak akurat sebanyak 233 $(64,7 \%)$ kode. Dari hasil uji statistik Chi-squared Test, diperoleh nilai p-value sebesar 0,03376 yang menunjukkan bahwa $\mathrm{H}_{\mathrm{a}}$ diterima dengan nilai $\operatorname{Odd}$ Ratio (OR) sebesar 1,7.

Kesimpulan: Terdapat hubungan antara ketepatan terminologi medis dengan keakuratan kode diagnosis rawat jalan oleh petugas kesehatan di Puskesmas Bambanglipuro Bantul. Peluang terminologi medis tidak tepat menyebabkan ketidakakuratan kode diagnosis rawat jalan 1,7 kali lebih besar dibandingkan terminologi medis tepat.
\end{abstract}

Kata kunci: Ketepatan, Terminologi Medis, Keakuratan, Kode Diagnosis, ICD-10

\begin{abstract}
Background: All medical and non-medical services in primary health center should be recorded in a document called medical record. One of the data that should be written down in the medical record document, SIMPUS, and P-Care is patient's diagnosis and its codes. The implementation of disease and clinical classification system which related to health problems should be appropriate with correct medical terminology. The determining of the diagnosis code is based on the disease classification system which stated by WHO today, that is called ICD-10. Based on documentation study by sample of 10 outpatient medical record documents coded by health care practitioners, found $60 \%$ inaccurate codes and $80 \%$ imprecise medical terminologies.
\end{abstract}

Objective: To know the correlation between the precision of medical terminology and the accuracy of diagnosis codes by health care practitioners in Puskesmas Bambanglipuro Bantul.

Methods: This research was analytical survey research with quantitative approach. The study design was cross-sectional. The population of this research was all outpatient diagnoses with their codes in January 2017. The samples were taken by systematic random sampling technique. Data analysis of this research was bivariate analysis with $R$ program.

Results: Based on 360 samples of outpatient diagnoses and their codes, there were 82 (22.8\%) precise medical terminologies and $278(77.2 \%)$ imprecise medical terminologies, as well as the accurate diagnosis codes were $127(35.3 \%)$ codes and the inaccurate diagnosis codes were $233(64.7 \%)$ codes. From the result of Chi-squared statistical test, it was obtained p-value of 0.03376 which showed that $\mathrm{H}_{\mathrm{a}}$ was accepted with OR of 1.7.

Conclusion: There is a correlation between the precision of medical terminology and the accuracy of diagnosis codes for outpatient by health care practitioners in Puskesmas Bambanglipuro Bantul. The probability of imprecise medical terminology causing inaccurate outpatient diagnosis code is 1.7 times bigger than the precise medical terminology.

Keywords: Precision, Medical Terminology, Accuracy, Diagnosis Code, ICD-10 


\section{PENDAHULUAN}

Semua pelayanan medis dan non medis di Puskesmas harus didokumentasikan dalam suatu berkas atau catatan yang disebut rekam medis. Untuk menunjang proses pelayanan, penyimpanan data, dan pelaporan data di Puskesmas, maka dikembangkan suatu sistem informasi yang disebut Sistem Informasi Manajemen Puskesmas (SIMPUS) dan aplikasi Primary Care BPJS (P-Care) khusus untuk pasien BPJS. SIMPUS dan P-Care merupakan salah satu bentuk rekam medis elektronik yang didalamnya terdapat catatan medis pasien.

Salah satu data yang dituliskan dalam berkas rekam medis, SIMPUS, dan P-Care adalah kode diagnosis yang diderita pasien. Pengodean diagnosis seharusnya dilakukan oleh petugas rekam medis yang memiliki kompetensi terkait klasifikasi dan kodefikasi penyakit sesuai dengan Kepmenkes Nomor 377 Tahun 2007 tentang Standar Profesi Perekam Medis dan Informasi Kesehatan yang disempurnakan dalam Permenkes Nomor 55 Tahun 2013 tentang Penyelenggaraan Pekerjaan Perekam Medis. Dalam peraturan tersebut disebutkan bahwa perekam medis memiliki wewenang untuk melaksanakan sistem klasifikasi klinis dan kodefikasi penyakit yang berkaitan dengan kesehatan dan tindakan medis sesuai terminologi medis yang benar. Pemberian kode diagnosis berdasarkan pada sistem klasifikasi penyakit yang ditetapkan oleh WHO saat ini yaitu International Statistical Classification of Diseases and Related Health Problems (ICD) Tenth Revision atau ICD-10.

Berdasarkan penelitian Pramono (2012) dari 385 berkas rekam medis di Puskesmas Gondokusuman II Kota Yogyakarta ditemukan 174 kode $(45,2 \%)$ akurat dan 211 kode $(54,8 \%)$ tidak akurat. Salah satu penyebab ketidakakuratan kode tersebut adalah tidak sesuainya kualifikasi SDM yang bertugas mengode diagnosis. Selain itu, ketidakakuratan kode diagnosis juga dapat disebabkan oleh ketidaktepatan terminologi medis yang digunakan oleh dokter. Penulisan singkatan atau istilah dalam penulisan diagnosis diperlukan adanya keseragaman dan konsisten dalam penggunaan terminologi medis sesuai ICD-10 untuk lebih meningkatkan keakuratan kode diagnosis (Khabibah dan Sugiarsi, 2013). Dalam penelitian Paramitasari (2015) juga disebutkan bahwa diagnosis yang belum menggunakan bahasa medis dan masih terdapat singkatan menjadi salah satu kendala dalam pengodean diagnosis pasien di Puskesmas Jepon.

Puskesmas Bambanglipuro sudah memiliki satu petugas rekam medis. Akan tetapi, pengodean diagnosis di Puskesmas Bambanglipuro Bantul tidak dilakukan oleh petugas rekam medis, melainkan dilakukan oleh petugas kesehatan yang tidak memiliki kompetensi kodefikasi penyakit, seperti dokter, bidan, dan perawat. Selain itu, kode diagnosis di Puskesmas Bambanglipuro Bantul tidak diperoleh dari buku ICD-10, melainkan dari internet. Puskesmas Bambanglipuro Bantul juga belum memiliki Standar Prosedur Operasional (SPO) yang mengatur tentang tata cara pengisian item pada lembar rawat jalan dan tata cara pengodean diagnosis.

Berdasarkan studi pendahuluan yang dilakukan oleh peneliti melalui wawancara pada tanggal 10 Januari 2017, petugas rekam medis Puskesmas Bambanglipuro Bantul menyatakan bahwa keakuratan kode diagnosis sangat penting karena berkaitan dengan validitas laporan Puskesmas. Akan tetapi, dari hasil studi dokumentasi terhadap 10 sampel berkas rekam medis rawat jalan yang dikode oleh petugas kesehatan, ditemukan $60 \%$ kode yang tidak akurat. Dari keseluruhan sampel berkas rekam medis rawat jalan tersebut terdapat $80 \%$ terminologi medis yang digunakan tidak tepat atau tidak sesuai dengan ICD-10. Dari $80 \%$ terminologi medis yang tidak tepat tersebut, 50\% kode diagnosis tidak akurat. Oleh karena itu, peneliti tertarik untuk melakukan penelitian mengenai hubungan ketepatan terminologi medis dengan keakuratan kode diagnosis rawat jalan oleh petugas kesehatan di Puskesmas Bambanglipuro Bantul. 
Penelitian ini bertujuan untuk mengetahui hubungan antara ketepatan terminologi medis dengan keakuratan kode diagnosis rawat jalan oleh petugas kesehatan di Puskesmas Bambanglipuro Bantul.

\section{Rekam Medis}

Huffman (1994) menyatakan bahwa rekam medis berisi data klinis pasien yang mencakup diagnosis dan tindakan yang dilakukan terhadap pasien. Data klinis biasanya dibagi menjadi data medis, data perawatan, dan data tambahan. Menurut Hatta (2013) rekam medis atau rekam kesehatan terbagi dalam dua jenis praktik, yaitu tradisional (kertas) dan modern (elektronik/komputer).

Dalam praktik manajemen rekam kesehatan secara tradisional, pengumpulan data dilakukan melalui format kertas dan disimpan dalam map, sedangkan praktik era modern mengumpulkan, menyimpan, dan menganalisis data atau informasi melalui sistem rekam kesehatan elektronik yang interaktif. Dalam rekam kesehatan kertas maupun komputerisasi, isi rekam kesehatan dibagi dalam data administrasi dan data klinis.

\section{Pengodean}

Menurut Budi (2011) kegiatan pengodean adalah pemberian penetapan kode dengan menggunakan huruf dan angka atau kombinasi antara huruf dan angka yang mewakili komponen data. Kegiatan yang dilakukan dalam pengodean meliputi kegiatan pengodean diagnosis penyakit dan pengodean tindakan medis. Tenaga rekam medis sebagai pemberi kode bertanggung jawab atas keakuratan kode. Menurut Abdelhak, dkk (2010) rekam medis dapat dikode dengan hasil yang dapat dipercaya, benar, dan lengkap serta dilakukan dengan tepat waktu sehingga dapat digunakan untuk pengambilan keputusan rekam medis. Berikut ini sembilan langkah dasar dalam menentukan kode menurut Kasim dalam Hatta (2013):

a. Tentukan tipe pernyataan yang akan dikode dengan ICD-10 Volume 3.

b. Lead term (kata panduan) untuk penyakit dan cedera biasanya merupakan kata benda yang memaparkan kondisi patologis.

c. Baca dengan seksama dan ikuti petunjuk catatan yang muncul di bawah istilah yang akan dipilih pada ICD-10 Volume 3.

d. Baca istilah yang terdapat dalam tanda kurung "()" sesudah lead term (kata yang terdapat di dalam tanda kurung merupakan modifier yang tidak akan mempengaruhi kode).

e. Ikuti secara hati-hati setiap rujukan silang (cross reference) dan perintah see dan see also yang terdapat dalam indeks abjad.

f. Lihat daftar tabulasi (ICD-10 Volume 1) untuk mencari nomor kode yang paling tepat.

g. Ikuti pedoman Inclusion dan Exclusion pada kode yang dipilih atau bagian bawah suatu bab (chapter), blok, kategori, atau subkategori.

h. Tentukan kode yang dipilih.

i. Lakukan analisis kuantitatif dan kualitatif data diagnosis yang dikode untuk memastikan kesesuaiannya dengan pernyataan dokter tentang diagnosis utama pada formulir rekam medis pasien guna menunjang aspek legal rekam medis.

\section{Terminologi Medis}

Terminologi medis adalah ilmu peristilahan medis (istilah medis) yang merupakan bahasa khusus antar profesi medis/kesehatan baik dalam bentuk tulisan maupun lisan; sarana komunikasi antara mereka yang berkecimpung langsung maupun tidak langsung di bidang asuhan/pelayanan kesehatan; serta sumber data dalam pengolahan dan penyajian dari diagnosis dan tindakan medis/operasi khususnya di bidang aplikasi ICD, ICOPIM, ICHI yang memerlukan akurasi dan presisi tinggi yang merupakan data dasar otentik bagi statistik morbiditas dan mortalitas (Nuryati, 2011). Menurut Kasim dan Erkadius dalam Hatta (2013) terminologi medis merupakan sistem yang digunakan untuk menata daftar kumpulan istilah medis penyakit, gejala, dan prosedur. Istilah-istilah penyakit atau kondisi gangguan kesehatan harus sesuai dengan 
istilah yang digunakan dalam suatu sistem klasifikasi penyakit.

\section{Ketepatan dan Keakuratan Kode Diagnosis}

Menurut Kamus Besar Bahasa Indonesia Online, ketepatan berasal dari kata 'tepat' yang mendapat awalan kedan akhiran -an. Kata tepat berarti hal yang betul atau lurus (arah, jurusan); kena benar (pada sasaran, tujuan, maksud, dan sebagainya); tidak ada selisih sedikitpun, tidak kurang dan tidak lebih, persis; betul atau cocok (tentang dugaan, ramalan, dan sebagainya); betul atau mengena (tentang perkataan, jawaban, dan sebagainya). Kode diagnosis dikatakan tepat dan akurat apabila sesuai dengan yang tertulis dalam ICD-10 sebagaimana penggunaannya di Indonesia diatur dalam Keputusan Menteri Kesehatan RI Nomor 50 Tahun 1998. Pada beberapa blok dalam ICD-10 tidak cukup hanya sampai karakter ketiga atau keempat, tetapi terdapat penambahan karakter kelima untuk menunjukkan letak anatomi pada Bab XIII, jenis fraktur dan cedera (tertutup atau terbuka) pada Bab XIX, serta macam aktivitas saat kejadian pada Bab XX. Menurut Hatta (2013) proses pengodean harus dimonitor untuk beberapa elemen sebagai berikut.

a. Konsisten bila dikode oleh petugas berbeda kode tetap sama (reliability)

b. Kode tepat sesuai diagnosis dan tindakan (validity)

c. Mencakup semua diagnosis dan tindakan yang ada di rekam medis (completeness)

d. Tepat waktu (timeliness)

ICD-10

Dalam Hatta (2013) disebutkan bahwa ICD-10 disebarluaskan dan digunakan secara internasional oleh WHO sejak tahun 1992. Indonesia menetapkan untuk menggunakan ICD-10 pada tahun 1998 melalui SK Menkes RI Nomor 50/MENKES/KES/SK/I/1998 (Budi, 2011). Menurut Hatta (2013) International Statistical Classification of Diseases and Related Health Problems atau ICD adalah sistem klasifikasi yang komprehensif dan diakui secara internasional. Sistem klasifikasi penyakit adalah sistem yang mengelompokkan penyakit-penyakit dan prosedur-prosedur yang sejenis ke dalam satu grup nomor kode penyakit dan tindakan yang sejenis. Penerapan pengodean sistem ICD digunakan untuk mengindeks pencatatan penyakit dan tindakan di sarana pelayanan kesehatan, masukan bagi sistem pelaporan diagnosis medis, pelaporan nasional dan internasional morbiditas dan mortalitas, tabulasi data pelayanan kesehatan bagi proses evaluasi perencanaan pelayanan medis, serta untuk penelitian epidemiologi dan klinis.

\section{METODE}

Jenis penelitian

Penelitian ini merupakan jenis penelitian survei analitik dengan pendekatan kuantitatif. Rancangan penelitian yang digunakan yaitu rancangan cross-sectional. Penelitian ini meneliti ketepatan terminologi medis (variabel bebas) dan keakuratan kode diagnosis rawat jalan oleh petugas kesehatan (variabel terikat) pada waktu bersamaan atau pada satu waktu tertentu, lalu menguji hubungan antara kedua variabel secara statistik.

\section{Populasi dan Sampel}

Menurut Sugiyono (2012) populasi adalah wilayah generalisasi yang terdiri dari atas objek/subjek yang mempunyai kualitas dan karakteristik tertentu yang ditetapkan oleh peneliti untuk dipelajari dan kemudian ditarik kesimpulannya. Populasi penelitian ini yaitu semua diagnosis rawat jalan beserta kodenya pada bulan Januari 2017 yang berjumlah 4.294 diagnosis. Jumlah sampel dalam penelitian ini sebanyak 360 diagnosis rawat jalan beserta kodenya. Sampel diambil dengan teknik systematic random sampling. Teknik pengumpulan data yaitu studi dokumentasi terhadap berkas rekam medis dan tampilan rekam medis elektronik dalam SIMPUS. Instrumen untuk mengumpulkan data yaitu checklist studi dokumentasi.

\section{Uji Validitas dan Reliabilitas}

Instrumen yang digunakan untuk mengukur ketepatan terminologi medis dan keakuratan kode diagnosis pasien rawat jalan dalam penelitian ini yaitu ICD10. Teknik validitas dalam penelitian ini menggunakan content validity (validitas 
isi). Instrumen ini sudah valid karena dibuat oleh WHO. Di Indonesia, penggunaan instrumen ini sudah diatur dalam Keputusan Menteri Kesehatan RI Nomor 50 Tahun 1998. Adapun penentuan ketepatan terminologi medis dan keakuratan kode diagnosis rawat jalan yang dilakukan oleh peneliti dikonsultasikan kepada dosen pengampu mata kuliah Kodefikasi dan Klasifikasi Penyakit dan Masalah Terkait (KKPMT) dari Universitas Gadjah Mada agar hasilnya dapat dipertanggungjawabkan.

Uji reliabilitas data dalam penelitian ini yaitu reliabilitas test-retest. Dalam penelitian ini, peneliti melakukan pengambilan data terhadap ketepatan terminologi medis pada lembar rawat jalan dan keakuratan kode diagnosis rawat jalan oleh petugas kesehatan secara berulang pada waktu yang berbeda.

\section{Analisis Data}

Tahapan-tahapan yang dilakukan dalam analisis bivariate menurut Notoatmodjo (2012) meliputi:

\section{Analisis Univariate (Analisis} Deskriptif)

Analisis univariate dilakukan untuk mendeskripsikan karakteristik masingmasing variabel penelitian. Dalam analisis ini, dihasilkan persentase ketepatan terminologi medis pada lembar rawat jalan dan keakuratan kode diagnosis rawat jalan oleh petugas kesehatan.

2. Analisis Bivariate

Analisis bivariate dilakukan terhadap dua variabel yang diduga berhubungan atau berkorelasi. Dalam penelitian ini, peneliti menguji hubungan antara ketepatan terminologi medis dengan keakuratan kode diagnosis rawat jalan oleh petugas kesehatan. Uji statistik yang digunakan yaitu Chi-squared Test dengan bantuan program $R$.

\section{HASIL DAN PEMBAHASAN}

\section{Ketepatan Terminologi Medis pada Lembar Rawat Jalan}

Data ketepatan terminologi medis didapatkan dari item diagnosis pada lembar rawat jalan. Terminologi medis yang digunakan dalam penulisan diagnosis dikatakan tepat apabila menggunakan istilah medis yang sesuai dengan ICD-10. Sebaliknya, terminologi medis dalam penulisan diagnosis dikatakan tidak tepat apabila menggunakan istilah medis yang tidak sesuai dengan ICD-10, seperti menggunakan istilah bahasa Indonesia atau singkatan. Berdasarkan hasil studi dokumentasi terhadap 360 diagnosis/kasus rawat jalan selama bulan Jnauari 2017, terdapat $82 \quad(22,8 \%)$ terminologi medis yang tepat dan 278 $(77,2 \%)$ terminologi medis yang tidak tepat. Berikut ini distribusi data ketepatan terminologi medis pada lembar rawat jalan di Puskesmas Bambanglipuro Bantul.

Distribusi Frekuensi Ketepatan

Terminologi Medis pada Lembar Rawat Jalan

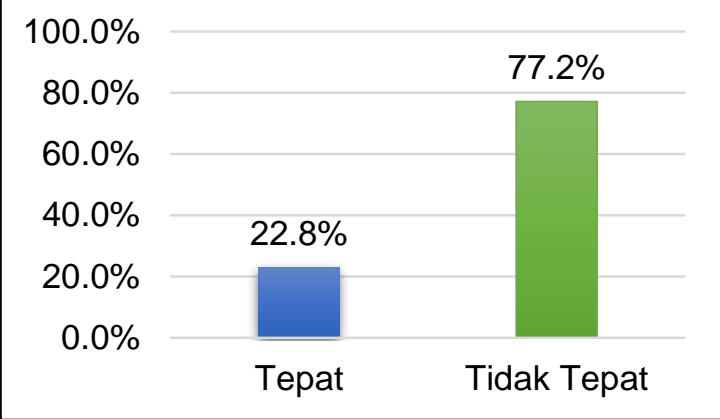

Gambar 1. Diagram Batang Ketepatan Terminologi Medis pada Lembar Rawat Jalan

Terminologi medis yang tidak tepat dikategorikan menjadi dua, yaitu menggunakan bahasa medis dan bahasa non medis. Berikut ini contoh terminologi medis tidak tepat yang menggunakan bahasa medis di Puskesmas Bambanglipuro Bantul.

Tabel 1. Penggunaan Bahasa Medis

\begin{tabular}{|c|c|c|}
\hline $\begin{array}{c}\text { No } \\
\text {. }\end{array}$ & $\begin{array}{c}\text { Terminologi } \\
\text { Medis pada } \\
\text { Lembar Rawat } \\
\text { Jalan }\end{array}$ & $\begin{array}{l}\text { Terminologi } \\
\text { Medis } \\
\text { Berdasarkan } \\
\text { ICD-10 }\end{array}$ \\
\hline 1 & $\begin{array}{l}\text { HT/HT S.I/HT } \\
\text { S.II/HT grade II }\end{array}$ & Hypertension \\
\hline 2 & $\mathrm{CHF}$ & $\begin{array}{l}\text { Congestive heart } \\
\text { failure }\end{array}$ \\
\hline 3 & Asma Br. & Bronchial asthma \\
\hline 4 & $\mathrm{VE}$ & Excoriation \\
\hline 5 & VL & Laceration \\
\hline
\end{tabular}

Penggunaan istilah HT sangat bervariasi. HT di bidang kesehatan merupakan istilah untuk tekanan darah tinggi. Istilah HT dikategorikan tidak tepat karena dalam ICD-10 tidak terdapat 
istilah singkatan. Penulisan yang tepat sesuai ICD-10 seharusnya adalah Hypertension. Berikut ini contoh terminologi medis tidak tepat yang menggunakan bahasa non medis di Puskesmas Bambanglipuro Bantul.

Tabel 2. Penggunaan Bahasa Non Medis

\begin{tabular}{|c|c|c|}
\hline No & $\begin{array}{l}\text { Terminologi } \\
\text { Medis pada } \\
\text { Lembar Rawat } \\
\text { Jalan }\end{array}$ & $\begin{array}{l}\text { Terminologi } \\
\text { Medis } \\
\text { Berdasarkan } \\
\text { ICD-10 }\end{array}$ \\
\hline 1 & $\begin{array}{l}\text { KIR dokter untuk } \\
\text { MK }\end{array}$ & $\begin{array}{l}\text { Pre-employment } \\
\text { examination }\end{array}$ \\
\hline 2 & Nyeri sendi (lutut) & $\begin{array}{l}\text { Arthralgia (knee } \\
\text { joint) }\end{array}$ \\
\hline 3 & Panas & Pyrexia \\
\hline 4 & Demam & Fever \\
\hline 5 & $\begin{array}{l}\text { Imunisasi } \\
\text { campak/ } \\
\text { Imunisasi campak } \\
\text { boster }\end{array}$ & $\begin{array}{l}\text { Immunization } \\
\text { against measles } \\
\text { alone }\end{array}$ \\
\hline
\end{tabular}

Istilah KIR dokter untuk MK merupakan salah satu terminologi medis yang dikategorikan tidak tepat karena menggunakan bahasa non medis. Istilah ini digunakan sebagai diagnosis pasien yang berkunjung untuk meminta surat keterangan sehat sebagai syarat melamar kerja. Penulisan istilah KIR dokter untuk melamar kerja yang tepat sesuai ICD-10 seharusnya adalah Pre-employment examination.

Salah satu permasalahan di RSUD Kota Semarang adalah penulisan terminologi yang ditulis oleh dokter tidak sesuai dengan ICD-10 sehingga tidak dapat dimengerti oleh petugas pengodean (Nugraheni dan Ernawati, 2015). Penetapan diagnosis seorang pasien merupakan kewajiban, hak, dan tanggung jawab tenaga medis yang terkait. Diagnosis yang ada dalam rekam medis harus diisi dengan lengkap dan jelas sesuai dengan arahan yang ada pada buku ICD-10 (Depkes, 1997).

\section{Keakuratan Kode Diagnosis Rawat Jalan oleh Petugas Kesehatan}

Data keakuratan kode diagnosis rawat jalan oleh petugas kesehatan diperoleh dari hasil studi dokumentasi terhadap 360 kode diagnosis rawat jalan, baik pada lembar rawat jalan maupun tampilan rekam medis elektronik.
Frekuensi untuk kategori akurat sebanyak 127 (35,3\%) kode diagnosis, sedangkan kategori tidak akurat sebanyak 233 (64,7\%) kode diagnosis. Distribusi data keakuratan kode diagnosis rawat jalan oleh petugas kesehatan, digambarkan dengan diagram batang berikut ini.

Gambar 2. Diagram Batang Keakuratan Kode

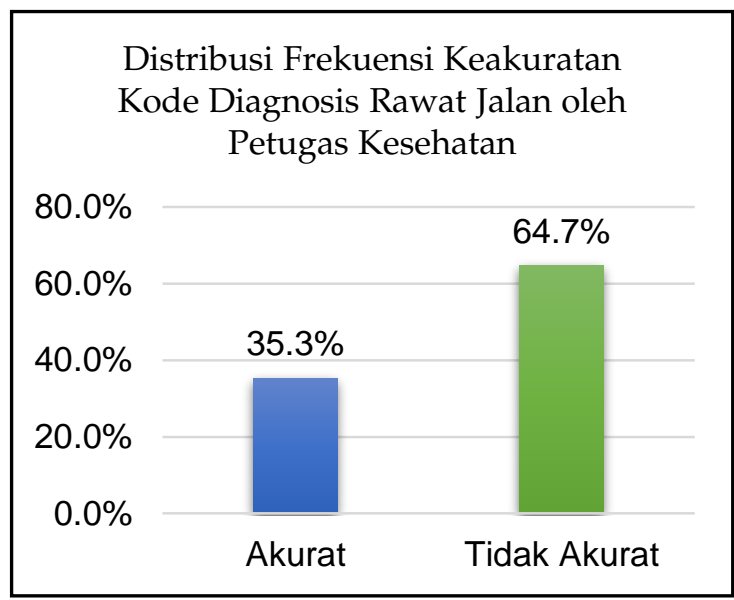

Diagnosis Rawat Jalan oleh Petugas Kesehatan

Ketidakakuratan kode diagnosis di Puskesmas Bambanglipuro Bantul dibagi menjadi tiga kategori, yaitu kode diagnosis empat atau lima karakter yang hanya dikode sampai karakter ketiga, kode diagnosis lima karakter yang hanya dikode sampai karakter keempat, dan kode diagnosis yang berbeda karakter ketiga, keempat, dan/atau kelima. Distribusi frekuensi kode diagnosis rawat jalan untuk kategori tidak akurat di Puskesmas Bambanglipuro Bantul dapat dirinci sebagai berikut.

Tabel 3. Distribusi Frekuensi Kode Diagnosis Rawat Jalan Kategori Tidak Akurat

\begin{tabular}{|c|c|c|c|}
\hline \multirow[t]{2}{*}{ No. } & \multirow[t]{2}{*}{ Kategori } & \multicolumn{2}{|c|}{$\begin{array}{c}\text { Tidak } \\
\text { Akurat }\end{array}$} \\
\hline & & f & $\%$ \\
\hline 1 & $\begin{array}{l}\text { Hanya sampai } \\
\text { karakter ketiga }\end{array}$ & 54 & 15,0 \\
\hline 2 & $\begin{array}{l}\text { Hanya sampai } \\
\text { karakter keempat }\end{array}$ & 13 & 3,6 \\
\hline 3 & $\begin{array}{l}\text { Berbeda karakter } \\
\text { ketiga, keempat, } \\
\text { dan/atau kelima }\end{array}$ & 166 & 46,1 \\
\hline Jumla & & 233 & 64,7 \\
\hline
\end{tabular}

Berikut ini contoh kode diagnosis yang seharusnya dikode empat atau lima karakter, tetapi hanya dikode sampai tiga karakter. 
Tabel 4. Kode Diagnosis Tidak Akurat (Hanya Sampai Karakter Ketiga)

\begin{tabular}{clcc}
\hline No & Diagnosis & $\begin{array}{c}\text { Kode } \\
\text { Pusk. }\end{array}$ & $\begin{array}{c}\text { Kode } \\
\text { Peneliti }\end{array}$ \\
\hline $\mathbf{1}$ & Panas/Febris/ & R50 & R50.9 \\
& Demam & & \\
$\mathbf{2}$ & Skizofrenia & F20 & F20.9 \\
$\mathbf{3}$ & PPOK & J44 & J44.9 \\
$\mathbf{4}$ & Fgitis & J02 & J02.9 \\
$\mathbf{5}$ & ISPA & J06 & J06.9 \\
\hline
\end{tabular}

Menurut WHO (2010), setiap bab dalam ICD-10 dibagi menurut blok. Setiap blok terdiri atas daftar kategori tiga karakter. Setiap kategori dibagi menjadi subkategori empat karakter. Subkategori empat karakter paling tepat digunakan untuk identifikasi, seperti variasi tempat yang berbeda pada kategori tiga karakter atau penyakit yang berdiri sendiri pada kategori tiga karakter untuk kondisi yang berkelompok.

Berdasarkan hasil studi dokumentasi, terdapat 13 kode diagnosis kasus Bab XIII dan Bab XIX yang membutuhkan karakter kelima untuk menunjukkan letak anatomi atau jenis fraktur, tetapi hanya dikode sampai karakter keempat. Berikut ini contoh kode diagnosis yang membutuhkan karakter kelima tetapi hanya dikode sampai karakter keempat di Puskesmas Bambanglipuro Bantul.

Tabel 5. Kode Diagnosis Tidak Akurat (Hanya Sampai Karakter Keempat)

\begin{tabular}{|c|c|c|c|}
\hline No. & Diagnosis & $\begin{array}{l}\text { Kode } \\
\text { Pusk. }\end{array}$ & $\begin{array}{l}\text { Kode } \\
\text { Peneliti }\end{array}$ \\
\hline 1 & $\begin{array}{l}\text { LBP } \\
\text { (Lokasi tidak } \\
\text { diketahui) }\end{array}$ & M54.5 & M54.59 \\
\hline 2 & $\begin{array}{l}\text { Arthritis } \\
\text { (Lokasi tidak } \\
\text { diketahui) }\end{array}$ & M13.9 & M13.99 \\
\hline 3 & $\begin{array}{l}\text { Myalgia } \\
\text { (Lokasi : } \\
\text { tangan) }\end{array}$ & M79.1 & M79.14 \\
\hline 4 & $\begin{array}{l}\text { Myalgia } \\
\text { (Lokasi : lengan } \\
\text { atas) }\end{array}$ & M79.1 & M79.12 \\
\hline 5 & $\begin{array}{l}\text { Myalgia } \\
\text { (Lokasi : lutut) }\end{array}$ & M79.1 & M79.16 \\
\hline
\end{tabular}

Hasil penelitian menunjukkan bahwa masih banyak kode pada kasus Bab XIII yang tidak dilengkapi karakter kelima untuk menunjukkan letak anatomi (site code). Menurut WHO (2010) beberapa blok dalam Bab XIII, Bab XIX, dan Bab XX perlu ditambahkan karakter kelima. Karakter kelima dalam Bab XIII menunjukkan kode letak anatomi (site code), karakter kelima dalam Bab XIX menunjukkan jenis fraktur dan cedera (terbuka atau tertutup), dan karakter kelima dalam Bab XX menunjukkan macam aktivitas saat kejadian.

Selain hanya dikode sampai karakter ketiga atau keempat, terdapat pula kode yang berbeda karakter ketiga, keempat, dan/atau kelima. Berdasarkan hasil studi dokumentasi, terdapat 166 kode diagnosis yang berbeda karakter ketiga, keempat, dan/atau kelima. Berikut ini contoh kode diagnosis yang berbeda karakter ketiga, keempat, dan/atau kelima di Puskesmas Bambanglipuro Bantul.

\begin{tabular}{llcc}
\multicolumn{3}{c}{ Tabel 6. Kode Diagnosis Berbeda Karakter } \\
\multicolumn{3}{c}{ Ketiga, Keempat, dan/atau Kelima } \\
\hline No. & Diagnosis & $\begin{array}{c}\text { Kode } \\
\text { Pusk. }\end{array}$ & $\begin{array}{c}\text { Kode } \\
\text { Peneliti }\end{array}$ \\
\hline $\mathbf{1}$ & ISPA & J00 & J06.9 \\
$\mathbf{2}$ & ISK & N30.0 & N39.0 \\
3 & KIR dokter & Z00.0 & Z02.1 \\
& untuk MK & & \\
4 & Vertigo & H82 & R42 \\
5 & HT & I15.9 & I10 \\
& HT S.I & & \\
& HT grade II & & \\
\hline
\end{tabular}

Kasus terbanyak yaitu diagnosis ISPA yang dikode J00. ISPA merupakan singkatan dari Infeksi Saluran Pernafasan Atas atau dalam bahasa Inggris yaitu Upper Respiratory Tract Infection. Dengan menggunakan leadterm 'Infection' pada ICD-10 Volume 3, maka kode yang tepat dan akurat seharusnya adalah J06.9.

Menurut Rohman, dkk kebijakan manajemen rekam medis tentang pengisian diagnosis dan keakuratan kode diagnosis memiliki pengaruh yang besar dalam jalannya pengisian diagnosis dan keakuratan kode diagnosis. Setiap fasilitas kesehatan, baik rumah sakit maupun puskesmas harus membuat kebijakan dan prosedur pengodean sesuai dengan tenaga dan fasilitas yang dimiliki. Kebijakan dan prosedur tersebut menjadi pedoman bagi petugas pengodean agar dapat melaksanakan pengodean dengan konsisten (Hatta, 2013). 
Hubungan Ketepatan Terminologi Medis dengan Keakuratan Kode Diagnosis Rawat Jalan oleh Petugas Kesehatan

Berdasarkan hasil studi dokumentasi, dapat diketahui bahwa dari 360 diagnosis/kasus rawat jalan terdapat 82 terminologi medis pada lembar rawat jalan tepat dan 278 terminologi medis pada lembar rawat jalan tidak tepat, serta 127 kode diagnosis akurat dan 233 kode diagnosis tidak akurat. Data hasil penelitian tersebut dapat diringkas dalam tabel kontingensi berikut ini.

Tabel 7. Hasil Uji Statistik Hubungan

Ketepatan Terminologi Medis dengan

Keakuratan Kode Diagnosis oleh Petugas Kesehatan

\begin{tabular}{|c|c|c|c|}
\hline & \multicolumn{2}{|c|}{$\begin{array}{c}\text { Keakuratan } \\
\text { Kode Diagnosis }\end{array}$} & \multirow[t]{2}{*}{ Jumlah } \\
\hline Ketepatan & Tidak & Tepat & \\
\hline $\begin{array}{l}\text { Terminologi } \\
\text { Medis }\end{array}$ & Tepat & & \\
\hline Tidak Tepat & 188 & 90 & 278 \\
\hline Tepat & 45 & 37 & 82 \\
\hline Jumlah & 233 & 127 & 360 \\
\hline
\end{tabular}

Uji statistik yang digunakan untuk menguji hipotesis yaitu Chi-squared Test dengan $\mathrm{H}_{\mathrm{a}}$ terdapat hubungan antara ketepatan terminologi medis dengan keakuratan kode diagnosis rawat jalan oleh petugas kesehatan di Puskesmas Bambanglipuro Bantul. Ho ditolak apabila $p$-value $<$. Besar $p$-value dalam penelitian ini yaitu 0,03376 dengan tingkat signifikansi $=0,05$. Hal ini menunjukkan bahwa $\mathrm{H}_{0}$ ditolak atau $\mathrm{H}_{\mathrm{a}}$ diterima, sehingga terdapat hubungan antara ketepatan terminologi medis dengan keakuratan kode diagnosis rawat jalan oleh petugas kesehatan di Puskesmas Bambanglipuro Bantul.

Ketepatan terminologi medis dapat mempengaruhi keakuratan kode diagnosis rawat jalan oleh petugas kesehatan. Hal ini terbukti dari sebanyak 37 terminologi medis yang tepat menghasilkan kode diagnosis yang akurat dan 188 terminologi yang tidak tepat menghasilkan kode diagnosis yang tidak akurat. Selain itu, nilai OR yang diperoleh sebesar 1,7. Hal ini berarti bahwa peluang terminologi medis yang tidak tepat menyebabkan ketidakakuratan kode diagnosis rawat jalan 1,7 kali lebih besar dibandingkan terminologi medis yang tepat.

Dalam penelitian Paramitasari (2015) disebutkan bahwa diagnosis yang belum menggunakan bahasa medis dan masih terdapat singkatan menjadi salah satu kendala dalam pengodean diagnosis pasien. Hal ini sesuai dengan penelitian Maryati (2016) bahwa terdapat hubungan antara ketepatan penulisan diagnosis dan keakuratan kode diagnosis kasus obstetri di RS PKU Muhammadiyah Sukoharjo dengan $p$-value sebesar 0,02 .

\section{PENUTUP}

\section{Kesimpulan}

a. Persentase ketepatan terminologi medis pada lembar rawat jalan di Puskesmas Bambanglipuro Bantul sebesar 22,8\%.

b. Persentase keakuratan kode diagnosis rawat jalan oleh petugas kesehatan di Puskesmas Bambanglipuro Bantul sebesar $35,3 \%$.

c. Terdapat hubungan antara ketepatan terminologi medis dengan keakuratan kode diagnosis oleh petugas kesehatan di Puskesmas Bambanglipuro Bantul $(p$-value $=0,03376 ;=0,05 ;$ dan $\mathrm{OR}=$ $1,7)$.

Saran

a. Puskesmas membuat SPO yang mengatur tentang tata cara pengisian item pada lembar rawat jalan, terutama item diagnosis agar ditulis dengan terminologi medis yang tepat sesuai ICD-10.

b. Puskesmas membuat SPO yang mengatur tentang tata cara pengodean diagnosis mengacu pada sembilan langkah dasar menurut Kasim dan Erkadius dalam Hatta (2013), menyediakan ICD-10, dan memberikan wewenang kepada petugas rekam medis untuk melakukan pengodean diagnosis.

c. Puskesmas melakukan stadardisasi atau pembakuan terminologi medis yang sesuai dengan ICD-10, serta selalu melakukan evaluasi terhadap ketepatan terminologi medis rawat jalan dan keakuratan kode diagnosis rawat jalan. 


\section{DAFTAR PUSTAKA}

Abdelhak, M., Grostik, S. A., Jacob, E. (2010). Health Information of $A$ Strategic Resource $2^{\text {nd }}$ Edition. Philadelphia: Sunders Company.

Budi, S. C. (2011). Manajemen Unit Kerja Rekam Medis. Yogyakarta: Quantum Sinergis Media.

Depkes RI. (1997). Pedoman Penyelenggaraan dan Prosedur Rekam Medis Rumah Sakit di Indonesia. Jakarta: Depkes RI.

Hatta, G. R. (2013). Pedoman Manajemen Informasi Kesehatan di Sarana Pelayanan Kesehatan. Jakarta: Universitas Indonesia.

Huffman, E. K. (1994). Health Information Management. Illinois: Physicians' Record Company.

Kamus Besar Bahasa Indonesia (KBBI) versi Online [internet]. http://kbbi.web.id/ Diakses pada tanggal 19 November 2016.

Khabibah, S. dan Sugiarsi, S. (2013). Tinjauan Ketepatan Terminologi Medis dalam Penulisan Diagnosis pada Lembaran Masuk dan Keluar di RSU Jati Husada Karanganyar. Jurnal Manajemen Informasi Kesehatan Indonesia. 1 (2): 46-52.

Maryati, W. (2016). Hubungan Antara Ketepatan Penulisan Diagnosis dengan Keakuratan Kode Diagnosis Kasus Obstetri di RS PKU Muhammadiyah Sukoharjo. Jurnal Ilmiah Rekam Medis dan Informatika Kesehatan. 6 (2): 1-7.

Notoatmodjo, S. (2012). Metodologi Penelitian Kesehatan. Jakarta: PT. Rineka Cipta.

Nugraheni, E. H. dan Ernawati, D. (2015). Tinjauan Pengetahuan Petugas Rekam Medis tentang Terminologi Medis dan Penentuan Kode Penyakit di RSUD Kota Semarang Tahun 2015. http://eprints.dinus.ac.id/ Diakses pada tanggal 30 Maret 2017.

Nuryati. (2011). Terminologi Medis: Pengenalan Istilah Medis. Yogyakarta: Quantum Sinergis Media.

Paramitasari, D. (2015). Pelaksanaan Pengodean Diagnosis di Puskesmas Jepon Kabupaten Blora. Tugas Akhir.
Yogyakarta: Rekam Medis Sekolah Vokasi UGM (tidak dipublikasikan).

Pramono, A. E. (2012). Hubungan antara Coder (Dokter dan Perawat) dengan Keakuratan Kode Diagnosis Berdasarkan ICD-10 di Puskesmas Gondokusuman II Kota Yogyakarta Tahun 2012. Skripsi. Surakarta: Kesehatan Masyarakat Fakultas Ilmu Kesehatan UMS (tidak dipublikasikan).

Rohman, H., Hariyono, W., Rosyidah. (2011). Kebijakan Pengisian Diagnosis Utama dan Keakuratan Kode Diagnosis pada Rekam Medis di Rumah Sakit PKU Muhammadiyah Yogyakarta. Jurnal Kesehatan Masyarakat. 5 (2): 162-232.

Sugiyono. (2012). Metodologi Penelitian Kualitatif dan Kuantitatif dan $R \& D$. Bandung: CV. Alfabeta.

WHO. (2010). International Statistical Classification of Disease and Related Health Problems, Tenth Revision, Volume 2 Instruction Manual. Geneva: WHO. 